\title{
Career Guidance and Counseling Program for Informal Education in Indonesia
}

\author{
Dede Rahmat Hidayat, Susi Fitri \& Siti Aminah Al-falathi \\ Universitas Negeri Jakarta \\ d_r_hidayat@yahoo.com, susi.fitri.kuliah@gmail.com \& alfalatihatih.com@gmail.com
}

\begin{abstract}
The aim of the present study is to develop career guidance and counseling programs for informal education. This program is provided to students who pursue their education at informal setting in senior high school. The present study employed Research and Development $(\mathrm{RnD})$ method. The product of this $\mathrm{RnD}$ research is Career Guidance and Counseling Program for informal education at senior high school level. This program is different with formal education because it has different characteristics. This program is development program (outreach program) which aims at developing and improving the willingness of the work. This career guidance program is complemented by various methods and media that are aligned by classical guidance activities in order to run well. Based on the expert assessment, the components involved in this program are considered as good category. This indicates that the career counseling program has material which is appropriate with the objectives of learning. The program also has appropriate method and learning media to support the teaching and learning activities in order to achieve the established goals. In addition, well-structured assessment is also implemented so that the conformity between the objectives, methods, materials and media can effectively support the availability of this career counseling program.
\end{abstract}

Keywords: career guidance and counseling program, outreach community, informal education

\section{INTRODUCTION}

Informal education is conducted to provide education access for wider community. Due to various factors, not all members of society have formal education opportunities. One of the factors is financial problem (Novita \& Neni, 2013), as the result, it causes them difficult to pay the education fee. This condition forces them to work hard over time to earn money so that they are not able to join formal education at school. Based on the situation, therefore, informal education becomes their alternatives.

As lower-class community group, the problems faced by students at informal school are diverse than students at formal schools. Gary et. al (2013) revealed that poverty is a factor that can affect the cognitive, physical and socio-emotional development of individuals. These developments are influenced by parenting style. Students who come from poor families may live in noisy, shabby and polluted environment and, as the result, they tend to be more stressful (Evans, 2004). That is why, poverty potentially makes the students' development is hung up.

Another problem the students face is related to career or work. They have no idea and planning about their career in the future. As it is known, career is determined by racial, ethnic, gander factors and socioeconomic classes (Blustein et al., 2002; Gushue \& Whitson, 2006; Liu, Ali, et al., 2004; Nelson, Englar-Carlson, Tierney, \& Hau, 2006; Valadez, 1998). Diemer \& Ali (2009) states that it is almost impossible to separate social class from career and work. In fact, the word career has connotation with social class with respect to the movement toward a new (and possibly better) social class position in society (Perry \& Wallace, 2013). Therefore, there are several studies on social classes that have shown how significant social class impacts on the development of children and adolescents.

Children living in poverty is lack of the environment exposure that stimulates their cognitive. They are limited exposure of printed media, appropriate toys, and digital education materials (Bradley \& Corwyn, 2002; Duncan \& Brooks-Gunn, 1997; Evans 2004). So, it is common that students from lower social class community tend to have low level of career expectation. Perry \& Wallace (2013) states that social class correlates positively with: (1) educational attainment, (2) centralization of work in men and women, (3) having good job in terms of financial, (4) enjoying activities during retirement.

Blustein (2006) suggests that career counseling should be linked with social class and classism along with other forms of

'isms' (eg, racism and sexism). Several studies have shown interesting findings related to how career, vocational, and profession may be seen as the indicator of success and those with higher social class background may see employment and vocational as a means of gaining expression and personal satisfaction (Blustein et al., in Liu 2011)

Social class problems also affect the challenge of informal education students at senior high school in determining and taking decisions to choose a job. Based on a survey conducted to 50 informal students, $60 \%$ had encountered difficulty in making choice for their profession and only $40 \%$ who had chosen an appropriate job for themselves. From the perspective of career development, the difficulty in making career decisions is related to the willingness to work that refers to the ability to freely making choices, including the choice of first job when entering the work environment and every subsequent career decision. Blustein $(2006,2008)$ defines the willingness to work as a perceived capacity to make decision about career or profession rather than forcing to have certain job. People with high willingness to work will likely see an expanse of job opportunities. Conversely, people with low willingness to work will likely feel they have limited choice of work, and possibly having a job that contrast with their personal preferences. 


\section{THEORETICAL FRAMEWORK}

1) Psychology of Work and Work Volition

Psychology of work (PWF), according to Blustein (2008), is developed to explain people's perception in working. He notes that for human being, working is mechanism to meet the needs of life, linkage, and selfdetermination. Moreover, working can lead to greater meaning of life and satisfaction (Blustein 2006, Ryan and Deci, 2000 and Schultheiss, 2003).

Work Volition (willingnes to work) is an important idea emphasizing on the principles of psychology of work. In PWF, Blustein $(2006,2008)$ focuses on general volition and structural constrains. Blustein $(2006,2008)$ defines the willingness to work as a perceived capacity to make a decision instead of forcing to have certain job. People with high willingness to work will likely see an expanse of job opportunities. Conversely, an individual with a low willingness to work will likely have limited choice of work.

\section{2) Social Class}

Social class is a category given to individual or group of people based on the available access in society (eg, education, income, and social). This predicate is provided by society through social agreement. According to Berger (in Kamanto 1993), social class is defined as "a type of stratification in which one's position in society is determined by economic condition". This is in line with Max Weber point of view that states the concept of social class is associated with one's position in society based on economic condition. The higher one's economic achievement is, the higher the position in society would be. This condition leads to a stereotyping for those who are considered as success people are categorized as higherclass society, and vice versa.

Social class can be used to see the world and filter information, experiences and relationship faced by society. They see themselves as part of economic hierarchy either as individual or member of a society group (Liu, 2011). Being a member of a particular social group signifies that they are aware of their status within the hierarchy (Wright in Liu, 2011). However, people who are involved in social group in the society will potentially experience classism. Classism is prejudice against or in favor of people belonging to a particular social class. In other words, people will experience discrimination based on the social class (Liu, 2011). Classicism is divided into four; 1) Upward Classism: it is a classic experienced by members of the upper social class group, 2) Downward Classism: it is a form of classicism experienced by poor people, such as feeling inferiority to hinger-class people,

(3) Lateral Classism: it is a form of classification that occurs within the same social class, in the form of horizontal ratio (Diwan, in Liu 2011), 4) Internalized Classism: it is a feeling of anxiety, depression, anger, and frustration resulting from the inability to keep one's position on a particular social class.

Therefore, in this study, social class will be assessed by using the Social Class Worldview Model constructed by William Ming Liu and Classism scale consisting of 1) upward, 2) downward, 3) lateral, and 4) internalized.

\section{3) Community Outreach Program}

It is assumed that individual's and community development are closely related. The community outreach program gives people the opportunity to get involved in community service on a regular basis. The members of the group are facilitated to build and determine strategies to develop their potential (Judith, 2011).

\section{RESEARCH METHOD}

The present Research and Development $(\mathrm{RnD})$ is chosen because it is appropriate with the objectives that will be achieved, that is to produce career counseling program. Borg

1) Direct community service is community guidance counseling for all members of the community. This community counseling program aims to provide education, information and skills for all members of the community through the participation of members. This approach is provided for educational and preventive efforts.

2) Indirect community service is an effort to create an environment that is responsive to the needs of the community as a whole. Environmental creation efforts are needed when communities have limitations to facilitate the development and competence of members in terms of community systems or systems support.

3) Direct client service is a community counseling program to facilitate the development of mental health for potential counselors or communities experiencing problems. This approach is counseling oriented.

4) Indirect clients service is an intervention-oriented approach to individual or group environments to meet their particular needs. Efforts is made in the form of advocacy.

The program is conducted for 20 sessions by using various available instructional media: LCD projectors, paper markers, learning activities using active learning method consisting of brainstorming, jigsaw, role play, problem base introduction, mind mapping, and practice. The material presented in the career guidance program consists of self-understanding, psychological development, soft skill, and technical skills such as using computers and English.

The program has been developed and then examined by expert and counselor of informal education. In general, the results indicate that career guidance program for informal education could be used in the real setting because it has good program criteria.

\section{CONCLUSION}

Career guidance and counseling program for informal education is established to develop community empowerment as it reaches the wider community (outreach community). Unlike the career guidance program in formal setting, the direction of career guidance at informal school is aimed at improving and encouraging the workforce that is considered as weak component of the students. In general, the program is developed by adopting community outreach program from Lewis consisting of 4 approaches, namely 1) direct community services, 2) indirect community services, 3) direct client services, and 4) interest client services. The program is conducted in 20 meetings by using various media and active learning methods. The provided guidance material consists of 
self-understanding, psychological development, soft skill and technical skills such as using computers and English.

\section{IMPLICATION}

Career counseling program is needed by informal education students to help them preparing their future career. In this career program, there are some materials that can enhance soft skill and improve the basic skills that are required in working environment.

\section{REFERENCEES}

Borg W.R., Gall, J.P., Gall, M.D. (1983). Educational Research, An Introduction. New York and London. Longman Inc.

Barnes, W.J. (1974). The effect of occupational investigation programs on ninth grade students. as measured by the career maturity inventory. Unpublished Disertation. Texas: A\&M University.

Blustein, D. L., (2006). The psychology of working: A new perspective for career development, counselling, and public policy.

Mahwah, NJ: Lawrence Erlbaum Associates.

Blustein, D. L, Kenna, A.C., Gill, N., DeVoy, Julia E. (2008). The Psychology of Working: A new framework for counselling practice and public policy. The Career Development Quarterly. Vol 56. 294-308.

Blustein, D. L., McWhirter, E. H., \& Perry J.C. (2005). An emancipatory communitarian approach to vocational development, theory, research, and practice. The Counseling Psychologist, 33(2) 141-179.

Bradley, R. H., \& Corwyn, R. F. (2002). Socioeconomic status and child development. Annual Review of Psychology, 53, 371-399

Corey. (2012). Theory and Practice of Group Counseling. United State: California State University

Dick, W., Carey, L., and Carey, J.O., (2001). The Systematic Design of Instruction (fifth edition). Longman.

Davis, Helen.,M,. (1977). Career Guidance, Counseling, Placement, and Follow Through Program For Rural School. Career Guidance and Counseling For Groups and individual. Career Guidance Practice A Resource Guide of suggested Group Guidance and Counseling Techniques for Use in Home, School, and Community. Journal of Eric. Washington DC.

Hershenson, David B., Paul W. Power, Michael Waldo. (1996).Community Counseling Contemporary Theory and Practice. USA. : Allyn \& Bacon

Ishak Abdulhak, Ugi Suprayogi, (2012). Penelitian Tindakan Dalam Pendidikan Non Formal, Jakarta: PT RajaGrafindo Pustaka.

Judith A Lewis, Michael D Lewis, Judy A Daniels, Michael JD'andrea. (1989). Community Counseling : A muliticultural-social justice perspective. Fourth edition. By Books/cole, cengange learning.

Johnshon, David. (2009). Reaching Out: Interpersonal Effectiveness and Self-Actualization Tenth Edition. University of Minnesota: Pearson.

Lewis, Judith A., Lewis, Michael D. (1989). Community counseling. Brooks/Cole Pub. Co.

Lewis, J., Lewis, M., Daniels, J., \& Andrea, M.,. (2011). Community Counseling: A Multicultural-Social Justice Perspective 4th.

Broooks Cole : Cengage Learning

Novita. Ana. Neni, (2013). Hambatan - hambatan warga belajar dalam proses pembelajaran program paket $\mathrm{c}$ di kecamatan pancung soal kabupaten pesisir selatan. Spektrum PLS. Vol 1 no 1

Fauzi, ika kartika. (2005). Model pendidikan bagi anak keluarga miskin. ISSN : 1411 - 2566. Universitas Islam Nusantara.
Rofi. Ahmad, (2015). Bimbingan dan Konseling Komunitas Untuk Mendukung Positive Youth Development (Penelitian Tindakan Partisipatoris Bersama Komunitas Schoolzone). Thesis tidak diterbitkan. Universitas Pendidikan Indonesia.

Robin. S, Espinoza. Adriana, (2005). Career-community development: a framework for career counseling and capacity building in rural communities. journal of employment counseling. Volume 42

Kotler, P. \& Keller, K. L. (2007). Manajemen pemasaran (12th ed). Jakarta: PT. Indeks.

Liu, William Ming. (2011). Social Class and Classism in the Helping Proffesions: Research, Theory, and Practice. LA: Sage 